\title{
Prediction of annual generations of the tomato leaf miner Tuta absoluta on tomato cultivations in Egypt
}

\author{
Hussein Sameir Salama ${ }^{1}$, Ibrahim El-Sayed Shehata ${ }^{1 *}$, Ibrahim Mohamed Ebada ${ }^{1}$, Mohamed Fouda ${ }^{2}$ and
} Ismail Abd El-Khaleik Ismail ${ }^{1}$

\begin{abstract}
Background: Tomato crop is the first vegetable crop in Egypt; it covers about 3\% of Egypt's total planted area. The tomato leaf miner Tuta absoluta is a polyphagous insect pest which feeds on several solanaceous plant species and preferentially on tomato causing high losses in productivity. This study aims to predict the annual generations and expected times for moth emergence in order to select the best time for the pest management.

Methods: Specimens of T. absoluta were collected from infested tomato field and reared under controlled temperatures to calculate the thermal requirements for development and completing the whole generation. The duration of different developmental stages of this insect and the life table parameters were estimated. The data were used to calculate the thermal constant and developmental zero for different developmental stages using the formula of Jasic (Bihemoslov 72:383-390, 1975) $y=n(t-x)$.

Results: Ecological studies were performed to evaluate the adverse effects of climatic changes on insect populations based on accumulation of the thermal requirements for development. The developmental zero was 5 . $79^{\circ} \mathrm{C}$ and the thermal constant was 171 DDs to complete the pupal stage development. Based on these values, the pupae development can be repeated 36 times during 2012 when the mean annual temperature was $22.8^{\circ} \mathrm{C}$. In Giza governorate, the average life cycle duration during 2012 was 52.44 days when the mean annual temperature was $22.8^{\circ} \mathrm{C}$, the number of annual generations was 8.05 , and the timing of the first generation was 11.66 days in April 2012 while the $8^{\text {th }}$ generation cycle was obtained after 28.2 days of January 2013. In Qena governorate, the mean annual temperature was increased to be $26.04^{\circ} \mathrm{C}$, so the annual generations increased to 9.52 . The first generation was recorded by the end of April 2012 while the $9^{\text {th }}$ generation was completed on 24.4 days of December 2012. In Merssa-Matrouh governorate, the mean annual temperature was $20.53^{\circ} \mathrm{C}$ and the number of the annual generations was found to be 7 during 2012. The first generation occurred on the day 19.86 of April 2012 while the $7^{\text {th }}$ generation cycle was detected after 30.98 days of January 2013. This means that there must be successive emergence of the adults but with variations during the different months and locations in correlation with variation of temperatures.
\end{abstract}

Conclusion: The accumulated thermal requirements appeared to be a very critical factor affecting insect development to complete the annual generations of T. absoluta in Egypt. This helps in designing the effective program and the best time for the pest management.

Keywords: Tuta absoluta, Thermal requirements, Climatic changes, Adult emergence, Annual generation

\footnotetext{
* Correspondence: Ib_shehata80@yahoo.com

${ }^{1}$ Pests and Plant Protection Department, National Research Centre, Cairo,

Egypt

Full list of author information is available at the end of the article
} 


\section{Introduction}

Egyptian agriculture is characterized by production of many exported vegetable crops such as tomato. The annual production of this crop in Egypt is 9,204,097 tons from about 9000 ha of the cultivated area (Moussa et al. 2013). So it is considered as the $5^{\text {th }}$ largest producer in the world.

Due to the shortage and regeneration of its cultivations, more than once during the year, it represents the main host plant to different insect species affecting crop quality and productivity such as the tomato leaf miner Tuta absoluta. This pest infests Solanaceous crops mainly tomato, potato, pepper, and eggplant in all developmental stages. The females deposited their eggs on all parts of the host plants: leaves, leaf neck, stem, sepals and especially fruits besides mining their leaves. After egg hatching, the larvae penetrate tomato leaves and feed on the leaf parenchyma tissues forming irregular mines that get longer and wider as the larvae continue to feed which can affect plant photosynthetic capability causing high loss of productivity. Investigations to evaluate the effect of climatic variables on $T$. absoluta are important to provide comprehensive data on its demographic parameters allowing for better design and timing of management strategies against this pest on tomato crop.

The present study aims to predict T. absoluta annual generations and expected times for moth frequency in the field under current and expected future climate changes by using the relationship between the accumulated thermal units expressed as degree days (DDs) and its population fluctuation in the experimental area.

\section{Material and methods}

A colony of T. absoluta was reared with larvae collected from infested tomato cultivations in Al Ayyat, Giza, for three generations according to Salama et al. (2014). Salama et al. (2015) studied the durations of different developmental stages of this insect and the life table parameters were estimated in the experimental farm affiliated to the laboratory. Follow-up of eggs deposited by the adult hatching to larvae and then to pupae was estimated, and also the larval and pupal durations were determined. These data were used to calculate the thermal constant and thermal threshold or developmental zero for different developmental stages using the formula of Jasic (1975).

$$
y=n(t-x)
$$

where $y$ is the thermal constant (total average temperature required for the development of each stage), $x$ is the thermal threshold, and $n$ is the average duration for the development of the stage at temperature $t$.
The meteorological data have been documented for estimation of the degree day's units, and daily temperature records were obtained from the Central Laboratory for Agricultural Climate (CLAC).

Since the emergence of moth will indicate the beginning of a new generation, the complete development of the larval stage to give normal pupae and its duration will be the main target of this study.

To present clear investigations on the role of mathematical calculations in the prediction of annual generations of the tomato leaf miner Tuta absoluta on tomato cultivations in Egypt, three different governorates, namely, Giza, Qena, and Merssa-Matrouh, were selected to apply the formula of Jasic (1975) as mentioned above. The selection of these governorates depended on variation in the climatic conditions where Qena governorate is known as one of the best Egyptian governorates in production of tomato and also because of its location in Upper Egypt, the average temperature around the year was high compared with other regions. While, Merssa-Matrouh governorate is a coastal city, so the average temperature was low around the year compared with other locations in Egypt. Also, T. absoluta was recorded firstly in Merssa-Matrouh governorate in 2009 and then it reached to other locations in Egypt in 2010. So it seems to be important to discuss and calculate the number and the expected frequencies of annual generations of $T$. absoluta in this governorate.

\section{Results}

Data presented in Table 1 indicate that the pupal duration of T. absoluta was $17.95 \pm 1.05$ days at $15.32^{\circ} \mathrm{C}$ and decreased to $8.45 \pm 1.3$ days when the temperature decreased to $26.03{ }^{\circ} \mathrm{C}$. The calculated value of developmental zero $(x)$ was $5.79{ }^{\circ} \mathrm{C}$ while the thermal constant $(y)$ was 171 degree days.

From these data, the expected frequencies of the adult emergence and the number of annual generations of the pest in the field can be determined in any locality in Egypt using the formula of Jasic (1975). The thermal constant and developmental zero of the generations of T. absoluta in three different governorates, Giza, Qena, and Merssa-Matrouh, were determined in this study.

From the data given in Table 1, it appears that the cycles for the insect emergence occur throughout the year and that determination of the pupal development at any time represents the expected time for the moth emergence.

Analyses of the data clearly indicate that the first cycle of adult emergence extended through 20.82 days in February. The second cycle began in the remaining 8.18 days of February to give $39.3 \%$ of adult emergence. This cycle extended through the first 9.98 days in the 
Table 1 Expected frequencies of emergence of Tuta absoluta moths in the Egyptian fields

\begin{tabular}{|c|c|c|c|c|c|c|}
\hline Month & Days $(n)$ & $t-x$ & $n(t-x)$ & Rate of emergence, \% & Expected date of adult emergence & Cycle no. \\
\hline Feb. 2012 & 20.823 & 8.212 & 171.00 & 100.00 & & \\
\hline Total & 20.823 & & 171.00 & $100 \%$ & 20.82, Feb. 2012 & 1 \\
\hline February & 8.18 & 8.212 & 67.17 & 39.30 & & \\
\hline March & 9.98 & 10.40 & 103.80 & 60.70 & & \\
\hline Total & 18.16 & & 171.00 & $100 \%$ & 9.98, Mar. 2012 & 2 \\
\hline March & 16.44 & 10.40 & 171.00 & 100.00 & & \\
\hline Total & 16.44 & & 171.00 & $100 \%$ & 26.42, Mar. 2012 & 3 \\
\hline March & 4.58 & 10.40 & 47.60 & 27.84 & & \\
\hline April & 7.145 & 17.27 & 123.42 & 72.20 & & \\
\hline Total & 11.73 & & 171.00 & $100 \%$ & 7.15, Apr. 2012 & 4 \\
\hline April & 9.90 & 17.27 & 171.00 & 100.00 & & \\
\hline Total & 9.90 & 17.27 & 171.00 & $100 \%$ & 17.05, Apr. 2012 & 5 \\
\hline April & 9.90 & 17.27 & 171.00 & 100.00 & & \\
\hline Total & 9.90 & 17.27 & 171.00 & $100 \%$ & 26.95, Apr. 2012 & 6 \\
\hline April & 3.06 & 17.27 & 52.85 & 30.91 & & \\
\hline May & 5.80 & 20.37 & 118.15 & 69.10 & & \\
\hline Total & 8.86 & & 171.00 & $100 \%$ & 5.8, May 2012 & 7 \\
\hline May & 8.40 & 20.37 & 171.00 & 100.00 & & \\
\hline Total & 8.40 & 20.37 & 171.00 & $100 \%$ & 14.2, May 2012 & 8 \\
\hline May & 8.40 & 20.37 & 171.00 & 100.00 & & \\
\hline Total & 8.40 & 20.37 & 171.00 & $100 \%$ & 22.6, May 2012 & 9 \\
\hline May & 8.40 & 20.37 & 171.00 & 100.00 & & \\
\hline Total & 8.40 & 20.37 & 171.00 & $100 \%$ & 31, May 2012 & 10 \\
\hline June & 7.42 & 23.04 & 171.00 & 100.00 & & \\
\hline Total & 7.42 & & 171.00 & $100 \%$ & 7.42, June 2012 & 11 \\
\hline June & 7.42 & 23.04 & 171.00 & 100.00 & & \\
\hline Total & 7.42 & & 171.00 & $100 \%$ & 14.84, June 2012 & 12 \\
\hline June & 7.42 & 23.04 & 171.00 & 100.00 & & \\
\hline Total & 7.42 & & 171.00 & $100 \%$ & 22.26, June 2012 & 13 \\
\hline June & 7.42 & 23.04 & 171.00 & 100.00 & & \\
\hline Total & 7.42 & 23.04 & 171.00 & $100 \%$ & 29.68, June 2012 & 14 \\
\hline June & 0.32 & 23.04 & 7.37 & 4.31 & & \\
\hline July & 6.76 & 24.21 & 163.66 & 95.71 & & \\
\hline Total & 7.08 & & 171.00 & $100 \%$ & 6.76, July 2012 & 15 \\
\hline July & 7.06 & 24.21 & 171.00 & 100.00 & & \\
\hline Total & 7.06 & & 171.00 & $100 \%$ & 13.82, July 2012 & 16 \\
\hline July & 7.06 & 24.21 & 171.00 & 100.00 & & \\
\hline Total & 7.06 & & 171.00 & $100 \%$ & 20.88, July 2012 & 17 \\
\hline July & 7.06 & 24.21 & 171.00 & 100.00 & & \\
\hline Total & 7.06 & & 171.00 & $100 \%$ & 27.94, July 2012 & 18 \\
\hline July & 3.06 & 24.21 & 74.10 & 43.33 & & \\
\hline August & 4.10 & 24.17 & 96.90 & 56.70 & & \\
\hline Total & 7.07 & & 171.00 & $100 \%$ & 4.01, August 2012 & 19 \\
\hline
\end{tabular}


Table 1 Expected frequencies of emergence of Tuta absoluta moths in the Egyptian fields (Continued)

\begin{tabular}{|c|c|c|c|c|c|c|}
\hline Month & Days (n) & $t-x$ & $n(t-x)$ & Rate of emergence, \% & Expected date of adult emergence & Cycle no. \\
\hline August & 7.07 & 24.17 & 171.00 & 100.00 & & \\
\hline Total & 7.07 & & 171.00 & $100 \%$ & 11.08, August 2012 & 20 \\
\hline August & 7.07 & 24.17 & 171.00 & 100.00 & & \\
\hline Total & 7.07 & & 171.00 & $100 \%$ & 18.15, August 2012 & 21 \\
\hline August & 7.07 & 24.17 & 171.00 & 100.00 & & \\
\hline Total & 7.07 & & 171.00 & $100 \%$ & 25.22, August 2012 & 22 \\
\hline August & 5.78 & 24.17 & 139.70 & 81.70 & & \\
\hline September & 1.44 & 21.67 & 31.30 & 18.30 & & \\
\hline Total & 7.22 & & 171.00 & $100 \%$ & 1.44, Sep. 2012 & 23 \\
\hline September & 7.89 & 21.67 & 171.00 & 100.00 & & \\
\hline Total & 7.89 & & 171.00 & $100 \%$ & 9.33, Sep. 2012 & 24 \\
\hline September & 7.89 & 21.67 & 171.00 & 100.00 & & \\
\hline Total & 7.89 & & 171.00 & $100 \%$ & 17.22, Sep. 2012 & 25 \\
\hline September & 7.89 & 21.67 & 171.00 & 100.00 & & \\
\hline Total & 7.89 & & 171.00 & $100 \%$ & 25.11, Sep. 2012 & 26 \\
\hline September & 4.89 & 21.67 & 105.97 & 61.97 & & \\
\hline October & 3.27 & 19.88 & 65.03 & 38.19 & & \\
\hline Total & 8.16 & & 171.00 & $100 \%$ & 3.27, Oct. 2012 & 27 \\
\hline October & 8.60 & 19.88 & 171.00 & 100.00 & & \\
\hline Total & 8.60 & & 171.00 & $100 \%$ & 11.87, Oct. 2012 & 28 \\
\hline October & 8.60 & 19.88 & 171.00 & 100.00 & & \\
\hline Total & 8.60 & & 171.00 & $100 \%$ & 20.47, Oct. 2012 & 29 \\
\hline October & 8.60 & 19.88 & 171.00 & 100.00 & & \\
\hline Total & 8.60 & & 171.00 & $100 \%$ & 29.07, Oct. 2012 & 30 \\
\hline October & 1.93 & 19.88 & 38.37 & 22.44 & & \\
\hline November & 8.58 & 15.45 & 132.63 & 77.56 & & \\
\hline Total & 10.51 & & 171.00 & $100 \%$ & 8.58, Nov. 2012 & 31 \\
\hline November & 11.09 & 15.45 & 171.00 & 100.00 & & \\
\hline Total & 11.09 & & 171 & $100 \%$ & 19.67, Nov. 2012 & 32 \\
\hline November & 10.33 & 15.45 & 159.60 & 93.33 & & \\
\hline December & 1.08 & 10.56 & 11.40 & 6.70 & & \\
\hline Total & 11.41 & & 171.00 & $100 \%$ & 1.08, Dec. 2012 & 33 \\
\hline December & 16.19 & 10.56 & 171.00 & 100.00 & & \\
\hline Total & 16.19 & & 171.00 & $100 \%$ & 17.27, Dec. 2012 & 34 \\
\hline December & 13.63 & 10.56 & 144.99 & 84.80 & & \\
\hline Jan. 2013 & 2.96 & 8.79 & 26.01 & 15.20 & & \\
\hline Total & 16.69 & & 171.00 & $100 \%$ & 2.96, Jan. 2013 & 35 \\
\hline January & 19.45 & 8.79 & 171.00 & 100.00 & & \\
\hline Total & 19.45 & & 171.00 & $100 \%$ & 22.41, Jan. 2013 & 36 \\
\hline January & 8.59 & 8.79 & 75.51 & 44.16 & & \\
\hline \multicolumn{5}{|c|}{ Total no. of cycles } & 36.44 & \\
\hline
\end{tabular}

following month (March) to attain the remaining $60.7 \%$ of adult emergence and to complete the $2^{\text {nd }}$ cycle. Again, the $3^{\text {rd }}$ cycle extended through within the same month. This phenomenon was continued until the end of January 2013, when the $36^{\text {th }}$ emergence cycle was detected after 22.41 days of January 2013. 


\section{Expected frequencies of annual generations of Tuta absoluta in the Egyptian fields}

The thermal constant represents heat units required to complete the insect development for one generation. To determine the rate of annual generation development of the insect, the formula was applied as follows:

$$
y=n(t-x)
$$

i.e., thermal constant $(y)=$ duration of life cycle of one generation $(n) \times$ \{temperature $(t)-$ developmental zero $(x)\}$.

So with insects reared at $26.03^{\circ} \mathrm{C}$, the duration of generation was 38.49 days.

$$
y=38.49(26.03-x) \quad \rightarrow \quad y=1001.89-38.49 \times
$$

While with insects reared at $15.32^{\circ} \mathrm{C}$, the duration of generation was 79.5 days.

$$
\begin{gathered}
y=79.5(15.32-x) \\
\text { when } 1=2
\end{gathered} \quad \rightarrow \quad \begin{aligned}
& y=1217.94-79.5 \times \\
& x=5.268^{\circ} \mathrm{C}
\end{aligned}
$$

So the calculation values were $5.268^{\circ} \mathrm{C}$ for developmental zero and 799.1 DDs for the thermal constant. So this formula has been applied to determine the thermal constant $(y)$ and developmental zero $(x)$ of the generations of T. absoluta in Giza, Qena, and Merssa-Matrouh depending on variation in climatic conditions in these governorates.

\section{In Giza governorate}

Studies on the female moth of $T$. absoluta showed that the heats required to complete life cycle per day and then per month in Giza governorate in 2012 were calculated as mentioned above and reported in Table 2.

Data in Table 2 indicate that when the developmental zero $(x)$ was $5.268^{\circ} \mathrm{C}$ and thermal constant (y) was $799.1 \mathrm{DDs}$, the life cycle duration was 91.52 days in February 2012 when the average temperature was $14{ }^{\circ} \mathrm{C}$; this decreased gradually in the following months where the minimum values of life cycle duration were recorded as $33.92,32.31$, and 32.37 days in June, July, and August 2012 at an average temperature of $28.83,30$, and $29.96{ }^{\circ} \mathrm{C}$, respectively. Then it increased to 36 days during September 2012 with a decrease of the temperature to $27.46{ }^{\circ} \mathrm{C}$. The longest duration was recorded in winter months (February, March, December 2012, and January 2013) where it reached to $91.53,73.18,72.1$, and 85.8 days when the monthly temperatures were $14,16.19,16.35$, and $14.58{ }^{\circ} \mathrm{C}$, respectively. The average duration of life cycle from February 2012 to January 2013 was 52.44 days when the mean annual temperature was $22.8^{\circ} \mathrm{C}$ and the number of annual generations was 8.05 generations.

To determine the rate of generation development, the formulas of Jasic (1975) was applied as follows:

Rate of generation development $(G)=$ no. of days per month $(n) \times$ [temperature $(t)$ - developmental zero $(x)] /$ thermal constant $(y)$.

Table 2 Calculated heat units required for the life cycle of females of Tuta absoluta in Giza governorate from February 2012 to January 2013

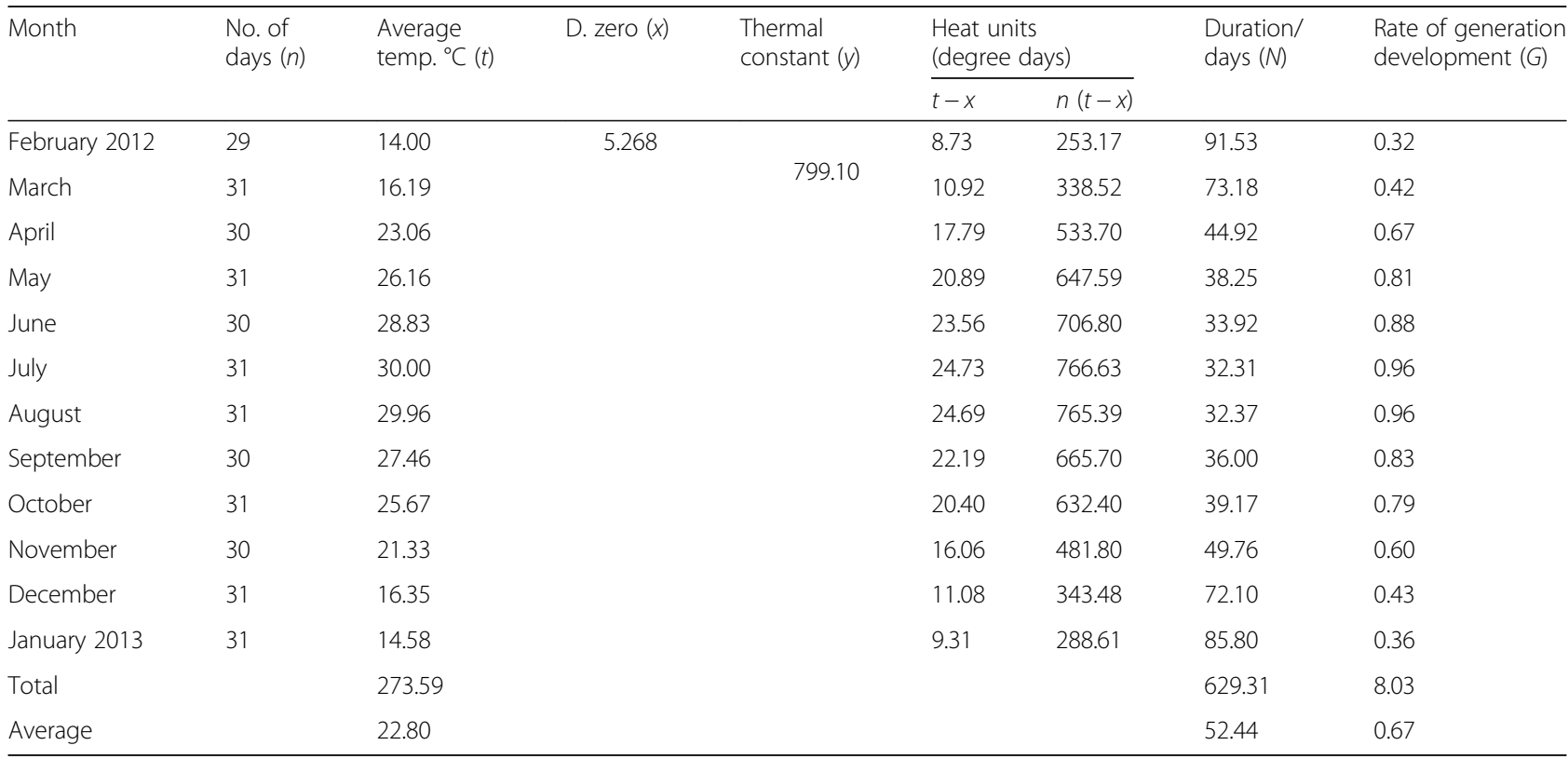


For instance, in February, heat units required for insect development (from egg to egg)

$$
\begin{aligned}
& G=n(t-x) / y \\
& \text { i.e., } \quad 29 \times 8.73 / 799.1=0.32 .
\end{aligned}
$$

So to determine the expected rate of annual generation development of the insect in the field, it is assumed that the duration of each cycle throughout the year is correlated with the thermal constant $(y)$ of the adult moth which amounts to 799.1 DDs. So calculations take into consideration that the accumulation of heat units started on the 1 February 2012. From the data given in Table 3, it appears that the cycles for the insect occur throughout the year and that determination of one generation development at any time represents the expected time for the moth emergence.
Analysis of the data clearly indicates that the expected time of the first generation was 11.66 in April 2012. This cycle passed through the remaining 18.34 days of April where the rate of generation development was 0.4; this cycle extends through the first 22.63 days in the following month (May) to attain 0.59 of the generation and to complete the $2^{\text {nd }}$ generation cycle in 22.63 of May 2012. Again, the $3^{\text {rd }}$ cycle extended through remaining 8.37 days within the same month where the rate of the $3^{\text {rd }}$ generation development was about 0.22 and then extended through the first 26.5 days of June where the rate was 0.78 to complete the $3^{\text {rd }}$ generation in the day 26.5 of June 2012.

This phenomenon was continued until the end of January 2013, when the $8^{\text {th }}$ generation cycle was detected after 28.2 days of January 2013.

\begin{tabular}{|c|c|c|c|c|c|c|}
\hline Month & Days $(n)$ & $t-x$ & $n(t-x)$ & Rate of generation development & Expected date of annual generations & Cycles no \\
\hline Feb. 2012 & 29.00 & 8.73 & 253.08 & 0.32 & 1, Feb. 2012 & \\
\hline March & 31.00 & 10.92 & 338.43 & 0.42 & & \\
\hline April & 11.66 & 17.79 & 207.43 & 0.26 & & \\
\hline Total & 71.66 & & 799.10 & 1.00 & 11.66, Apr. 2012 & 1 \\
\hline April & 18.34 & 17.79 & 326.27 & 0.41 & & \\
\hline May & 22.634 & 20.89 & 472.83 & 0.59 & & \\
\hline Total & 40.97 & & 799.10 & 1.00 & 22.63, May 2012 & 2 \\
\hline May & 8.37 & 20.89 & 174.85 & 0.22 & & \\
\hline June & 26.50 & 23.56 & 624.25 & 0.78 & & \\
\hline Total & 34.87 & & 799.10 & 1.00 & 26.5, Jun. 2012 & 3 \\
\hline June & 3.50 & 23.56 & 82.46 & 0.10 & & \\
\hline July & 28.977 & 24.73 & 716.64 & 0.90 & & \\
\hline Total & 32.48 & & 799.10 & 1.00 & 28.98, Jul. 2012 & 4 \\
\hline July & 2.02 & 24.73 & 49.95 & 0.055 & & \\
\hline August & 30.34 & 24.69 & 749.10 & 0.945 & & \\
\hline Total & 32.36 & & 799.10 & 1.00 & 30.34, Aug. 2012 & 5 \\
\hline August & 0.66 & 24.69 & 16.30 & 0.02 & & \\
\hline September & 30.00 & 22.19 & 665.70 & 0.83 & & \\
\hline October & 5.74 & 20.40 & 117.10 & 0.15 & & \\
\hline Total & 36.40 & & 799.10 & 1.00 & 6.74, Oct. 2012 & 6 \\
\hline October & 25.26 & 20.40 & 515.30 & 0.64 & & \\
\hline November & 17.67 & 16.06 & 283.80 & 0.36 & & \\
\hline Total & 42.93 & & 799.10 & 1.00 & 17.67, Nov. 2012 & 7 \\
\hline November & 12.33 & 16.06 & 198.02 & 0.25 & & \\
\hline December & 31.00 & 11.08 & 343.48 & 0.43 & & \\
\hline Jan. 2013 & 27.67 & 9.31 & 257.61 & 0.32 & & \\
\hline Total & 71.00 & & 799.10 & 1.00 & 28.2, Jan. 2013 & 8 \\
\hline Jan. 2013 & 3.33 & 9.31 & 31.00 & 0.038 & & \\
\hline \multicolumn{5}{|c|}{ Total no. of cycles } & 8.038 & \\
\hline
\end{tabular}

Table 3 Expected frequencies of annual generations of Tuta absoluta in Giza governorate during 2012 
In Qena governorate

Data in Table 4 indicate that when the developmental zero $(x)$ was $5.268^{\circ} \mathrm{C}$ and thermal constant $(y)$ was 799.1 DDs, the life cycle duration was 65.02 days in February 2012 when the average temperature was $17.56{ }^{\circ} \mathrm{C}$; this decreased gradually in the following months where the minimum values of life cycle duration were recorded as 27.9 and 27.47 days in June and July 2012 at an average temperature of 33.87 and $34.36{ }^{\circ} \mathrm{C}$, respectively. Then it increased to 28.71 days during August 2012 with a decrease of the temperature to $33.1{ }^{\circ} \mathrm{C}$. The longest duration was recorded in winter months (February and December 2012 and January 2013) where it reached to 65.02, 69.25 and 73.1 days when the monthly temperature was $17.56,16.81$ and $16.2^{\circ} \mathrm{C}$, respectively. The average life cycle duration from February 2012 to January 2013 was 43.74 days when the mean annual temperature was $26.04{ }^{\circ} \mathrm{C}$ and the number of annual generations was calculated to be 9.53 generations per year. To determine the rate of generation development during 2012 in Qena governorate, the formula of Jasic (1975) has been applied as mentioned before.

From the data given in Table 5, it appears that the cycles for the insect occur throughout the year and that determination of one generation development at any time represents the expected time for the moth emergence. Analysis of the data presented in Table 5 indicates that the expected time of the first generation occurred on the day 30.59 of March 2012. The second cycle passed through the remaining 0.41 day of March where the rate of generation development was 0.01 . This cycle extended through April and the first 5.18 days in the following month (May) to attain 0.17 of generation and to complete the $2^{\text {nd }}$ generation cycle in the day 5.18 of May 2012. Again, the $3^{\text {rd }}$ cycle extended through the remaining 25.82 days within the same month where the rate of the $3^{\text {rd }}$ generation development was about 0.84 and then extended through the first 4.59 days of June where the rate of development was 0.16 to complete the $3^{\text {rd }}$ generation in the day 4.59 of June 2012 .

This phenomenon was continued until the end of December 2012, when the $9^{\text {th }}$ generation cycle was detected after 24.43 days of this month. The accumulated heat units (thermal constant) required to complete the last generation did not reach to 799.1 DDs during January 2013 since it was 414.65 DDs, so the last generation was not complete where the rate of generation development was about 0.52 . So the number of annual generations during 2012 was found to be 9.52 cycles in Qena governorate.

\section{In Merssa-Matrouh}

Data in Table 6 indicate that when the developmental zero $(x)$ was $5.268{ }^{\circ} \mathrm{C}$ and thermal constant $(y)$ was 799.1 DDs, the life cycle duration was 104.6 days in February 2012 when the average temperature was $12.91{ }^{\circ} \mathrm{C}$; this decreased gradually in the following months where the minimum values of life cycle duration were recorded as 36.11 days in August 2012 at an average temperature of $27.4^{\circ} \mathrm{C}$ and then increased to 39.4 days during September 2012 with decrease of the temperature to $25.55^{\circ} \mathrm{C}$. The longest duration was recorded in winter months (February, March, December 2012, and January 2013) where it reached to $104.6,82.64,75.74$, and 95.36 days when the monthly temperatures were 12.91, 14.94, 15.82 , and $13.65^{\circ} \mathrm{C}$, respectively. The average life cycle

Table 4 Calculated heat units required for life cycle of females of Tuta absoluta in Qena governorate during 2012

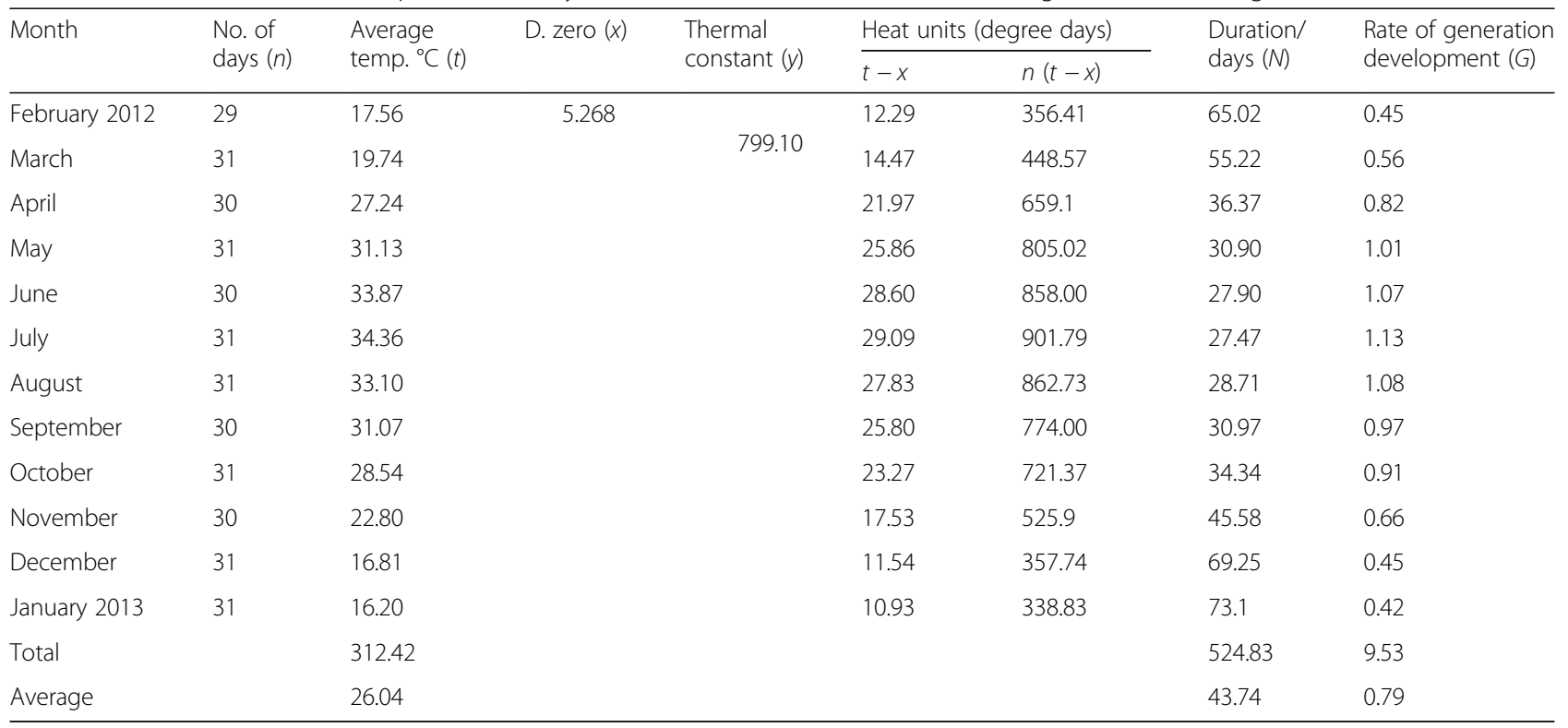


Table 5 Expected frequencies of annual generations of Tuta absoluta during 2012 in Qena governorate

\begin{tabular}{|c|c|c|c|c|c|c|}
\hline Month & Days $(n)$ & $t-x$ & $n(t-x)$ & Rate of generation development & Expected date of annual generations & Cycles no. \\
\hline Feb. 2012 & 29 & 12.29 & 356.41 & 0.45 & 1, Feb. 2012 & \\
\hline March & 30.594 & 14.47 & 442.69 & 0.55 & & \\
\hline Total & 59.59 & & 799.1 & 1 & 30.59, Apr. 2012 & 1 \\
\hline March & 0.41 & 14.47 & 5.93 & 0.01 & & \\
\hline April & 30 & 4.97 & 659.1 & 0.82 & & \\
\hline May & 5.184 & 25.86 & 134.07 & 0.17 & & \\
\hline Total & 35.59 & & 799.1 & 1 & 5.18, May 2012 & 2 \\
\hline May & 25.82 & 25.86 & 667.71 & 0.84 & & \\
\hline June & 4.594 & 28.6 & 131.39 & 0.16 & & \\
\hline Total & 30.414 & & 799.1 & 1 & 4.59, Jun. 2012 & 3 \\
\hline June & 25.41 & 28.6 & 726.73 & 0.91 & & \\
\hline July & 2.488 & 29.09 & 72.37 & 0.09 & & \\
\hline Total & 27.898 & & 799.1 & 1 & 2.49, Jul. 2012 & 4 \\
\hline July & 27.47 & 29.09 & 799.1 & 1 & & \\
\hline Total & 27.47 & & 799.1 & 1 & 29.96, Jul. 2012 & 5 \\
\hline July & 1.04 & 29.09 & 30.0 & 0.04 & & \\
\hline August & 27.625 & 27.83 & 768.8 & 0.96 & & \\
\hline Total & 28.665 & & 799.1 & 1 & 27.63, Aug. 2012 & 6 \\
\hline August & 3.375 & 27.83 & 93.93 & 0.12 & & \\
\hline September & 27.332 & 25.8 & 705.17 & 0.88 & & \\
\hline Total & 30.707 & & 799.1 & 1 & 27.33, Sep. 2012 & 7 \\
\hline September & 2.67 & 25.8 & 68.89 & 0.09 & & \\
\hline October & 31 & 23.27 & 721.37 & 0.9 & & \\
\hline November & 0.504 & 17.53 & 8.84 & 0.01 & & \\
\hline Total & 33.99 & & 799.1 & 1 & 0.5, Nov. 2012 & 8 \\
\hline November & 29.5 & 17.53 & 517.14 & 0.65 & & \\
\hline December 2012 & 24.433 & 11.54 & 281.96 & 0.35 & & \\
\hline Total & 53.933 & & 799.1 & 1 & 24.43, Dec. 2012 & 9 \\
\hline December 2012 & 6.57 & 11.54 & 75.82 & 0.095 & & \\
\hline \multirow[t]{2}{*}{ January 2013} & 31 & 10.93 & 338.83 & 0.42 & & \\
\hline & 37.57 & & 414.65 & 0.52 & & \\
\hline Total no. of cycles & & & & 9.52 & & \\
\hline
\end{tabular}

duration from February 2012 to January 2013 was 59.6 days when the mean annual temperature was $20.53^{\circ} \mathrm{C}$ and the number of annual generations was found to be 6.98 generations.

To determine the rate of annual generation development in Merssa-Matrooh during 2012, the formula of Jasic (1975) has been applied as mentioned above.

Analysis of the data presented in Table 7 indicates that expected the time of the first generation occurred on the day 19.86 of April 2012. This cycle passed through the remaining 10.14 days of April where the rate of generation development was 0.18 ; this cycle passed through May and extended till the first 8.226 days in the following month (June 2012) to attain 0.19 of generation and to complete the $2^{\text {nd }}$ generation cycle in the day 8.23 of June 2012. Again, the $3^{\text {rd }}$ cycle extended through the remaining 21.77 days within the same month where the rate of the $3^{\text {rd }}$ generation development was 0.51 and then extended through the first 17.88 day of July where the rate was 0.49 to complete the $3^{\text {rd }}$ generation in the day 17.88 of July 2013.

This phenomenon was continued until the end of January 2013, when the $7^{\text {th }}$ generation cycle was detected after 30.98 days of this month. So the number of annual generation in Merssa-Matrouh during 2012 was 7 generations. 
Table 6 Calculated heat units required for life cycle of females of Tuta absoluta in Merssa-Matrouh governorate during 2012

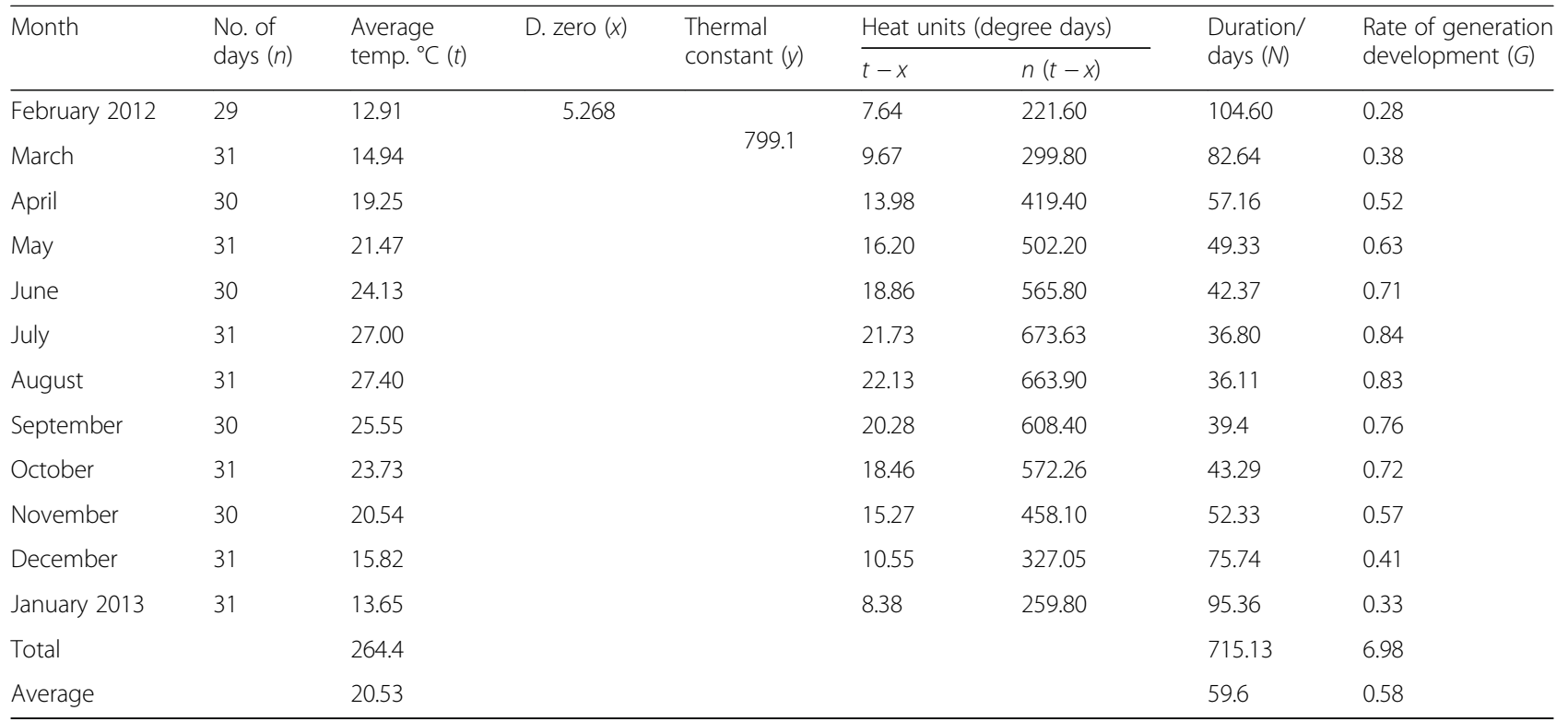

\section{Discussion}

The ecological studies showed that the rate of infestation rate by $T$. absoluta differs in different tomato strains and in different governorates as affected by environmental conditions.

All different stages of $T$. absoluta presented the entire year seasons in the samples collected from tomato plants. This suggested that the insect emergence occurs throughout the year.

The climate change certainly affects the status of abundance of $T$. absoluta in the field. According to Zalom and Wilson (1982), the rate of insect development is based on the accumulation of heat measured in physiological rather than chronological time. Zalom et al. (1983) reported that the thermal units provide a valuable tool for insect pest control, in forecasting infestations monitoring and timing of insecticide applications. Accumulated thermal units have been used to predict the seasonal development and emergence of various insects (Sevacherian et al. 1977; Farag et al. 2009). So the present investigations can help in predicting $T$. absoluta annual generations and expected times of moth frequency in the field under current and expected future climate changes by using the relationship between the accumulated thermal heat units expressed as degree days and its population fluctuation in the experimental area.

Thus, the number of cycles of pupal development termination in the field can be calculated by dividing the heat required during a certain period by the thermal constant. Our results indicated that during 2012, the recorded mean annual temperature was $22.8^{\circ} \mathrm{C}$ and the pupation development rate can be repeated 36 times. This means that there must be successive emergence of the adults but with variations during the different months in correlation with temperature.

Our data clearly indicated that the cycles for the insect emergence occur throughout the year, and the first cycle of adult emergence extended through 20.82 days in February. The second cycle began in the remaining 8.18 days of February and extended through the first 9.98 days in the following month (March) to complete the $2^{\text {nd }}$ cycle. Again, the $3^{\text {rd }}$ cycle extended through within the same month. This phenomenon was continued until the end of January 2013, when the $36^{\text {th }}$ emergence cycle was detected after 22.41 days of January 2013. So the thermal constant of the pupal stage can serve as an approach to control this insect pest. Many trails carried out to estimate the role of thermal units in the prediction of the sequence of adult emergence of the insect pests in the field. This method was recommended in the prediction of the pest generation mathematically. This agrees with Hamdy (1990b) when used this method to determine the chemical control of Lepidosaphes pallida in appropriate time of crawler abundance in the field.

As already mentioned, variation in climatic conditions in different governorates certainly affects the insect development and it follows that insect generations will differ. Our results showed that the duration of the insect generation reared at $26.03^{\circ} \mathrm{C}$ was 38.49 days compared to 79.5 days when reared at $15.32^{\circ} \mathrm{C}$. So the calculated developmental zero was $5.268^{\circ} \mathrm{C}$ and the thermal constant was 799.1 DDs. So the expected frequencies of annual generations were determined in three governorates, Giza, Qena (one of the largest cultivated tomato areas), and Merssa-Matrouh (along the Mediterranean coast). 
Table 7 Expected frequencies of annual generations of Tuta absoluta Merssa-Matrouh governorate during 2012

\begin{tabular}{|c|c|c|c|c|c|c|}
\hline Month & Days $(n)$ & $t-x$ & $n(t-x)$ & Rate of generation development & Expected date of annual generations & Cycles no. \\
\hline February 2012 & 29 & 7.64 & 221.6 & 0.28 & 1, Feb. 2012 & \\
\hline March & 31 & 9.67 & 299.8 & 0.38 & & \\
\hline April & 19.864 & 13.89 & 277.7 & 0.35 & & \\
\hline Total & 79.86 & & 799.1 & 1 & 19.86, Apr. 2012 & 1 \\
\hline April & 10.14 & 13.89 & 141.76 & 0.18 & & \\
\hline May & 31 & 16.2 & 502.2 & 0.63 & & \\
\hline June & 8.226 & 18.86 & 155.14 & 0.19 & & \\
\hline Total & 49.37 & & 799.1 & 1 & 8.23, Jun. 2012 & 2 \\
\hline June & 21.77 & 18.86 & 410.58 & 0.51 & & \\
\hline July & 17.88 & 21.73 & 388.52 & 0.49 & & \\
\hline Total & 39.65 & & 799.1 & 1 & 17.88, Jul. 2012 & 3 \\
\hline July & 13.12 & 21.73 & 285.1 & 0.4 & & \\
\hline August & 23.226 & 22.13 & 514 & 0.64 & & \\
\hline Total & 36.346 & & 799.1 & 1 & 23.23, Aug. 2012 & 4 \\
\hline August & 7.77 & 22.13 & 171.95 & 0.22 & & \\
\hline September & 30 & 20.28 & 608.4 & 0.76 & & \\
\hline October & 1.016 & 18.46 & 18.75 & 0.02 & & \\
\hline Total & 38.79 & & 799.1 & 1 & 1.02, Oct. 2012 & 5 \\
\hline October & 29.98 & 18.46 & 553.43 & 0.69 & & \\
\hline November & 16.09 & 15.27 & 245.67 & 0.31 & & \\
\hline Total & 46.07 & & 799.1 & 1 & 16.09, Nov.2012 & 6 \\
\hline November & 13.91 & 15.27 & 212.41 & 0.27 & & \\
\hline December & 31 & 10.55 & 327.05 & 0.41 & & \\
\hline January 2013 & 30.98 & 8.38 & 259.64 & 0.32 & & \\
\hline Total & 75.89 & & 799.1 & 1 & 30.98, Jan.2013 & 7 \\
\hline January 2013 & 0.02 & 8.38 & 0.17 & 0 & & \\
\hline \multicolumn{5}{|c|}{ Total no. of cycles } & 7 & \\
\hline
\end{tabular}

Ecological studies reported that variation of the recorded climatic conditions in all tested governorates (Giza, Qena, and Merssa-Matrouh) affected the biological aspects of the insect. So using Jasic's formula is a very important tactic for the prediction and calculation of the frequencies of the insect generation for selecting the best time with designing the effective methods for insect management. This approach has been adopted by previous authors with various insect species, e.g., Sevacherian et al. (1977); Farag et al. (2009) stated that accumulated thermal units have been used to predict the seasonal development and emergence of various insects. Vercher et al. (2010) reported 10-12 generations per year in South America. While Varges (1970) found 7-8 annual generations in Chile. In the Mediterranean basin up to 9 generations were observed in southern Italy (Sannino and Espinosa 2010) and 11-13 generations have been predicted under Egyptian open field conditions by applying a degree day accumulation model as mentioned by Abolmaaty et al. (2010) in their studies on the same insect pest. Hamdy (1990a) stated that the expected date for generations of the oleander scale, Aspidiootus hederae can be easily detected and help in designing a program for pest management.

\section{Conclusion}

The obtained data evaluated the effects of the change in climatic conditions, and the accumulated thermal requirements appeared to be a very critical factor affecting insect development to complete the annual generations of T. absoluta in Egypt. This helps in designing the effective program and the best time to manage this pest under field conditions.

\section{Acknowledgements}

The authors are very grateful to the National Research Centre for providing all required facilities to complete this work. Many thanks to all members in the Pests and Plant Protection Department, National Research Centre for providing the required help not only in the laboratory but also in the experimental field. 


\section{Funding}

This work was funded by the National Research Centre.

\section{Availability of data and materials}

All datasets on which abstracted of the study have been drawn are presented in the main manuscript. All tables or figures have not been published anywhere else before. All data and materials are available.

\section{Significant statement}

This study helps in designing the effective program and the best time to manage the insect pests by prediction of the date of pest emergence.

\section{Authors' contributions}

HSS and MF design the experiment, while IME and IES collected the insect specimens and reared the pest under controlled temperatures publications. IES obtained the results, constructed the tables, and edited the manuscript. HSS and IAEI revised it and all authors read and approved the final format.

\section{Ethics approval and consent to participate}

Not applicable

\section{Consent for publication}

Not applicable

\section{Competing interests}

The authors declare that they have no competing interests.

\section{Publisher's Note}

Springer Nature remains neutral with regard to jurisdictional claims in published maps and institutional affiliations.

\section{Author details}

${ }^{1}$ Pests and Plant Protection Department, National Research Centre, Cairo, Egypt. ${ }^{2}$ Zoology and Entomology Department, Faculty of Science, Al Azhar University, Cairo, Egypt.

Received: 17 March 2019 Accepted: 6 May 2019

Published online: 07 June 2019

\section{References}

Abolmaaty SM, Hassanein MK, Khalil AA, Abou-Hadid AF (2010) Impact of climatic changes in Egypt on degree day's units and generation number for tomato leaf miner moth Tuta absoluta, (Meyrick) (Lepidoptera: Gelechiidae). Nat Sci 8(11):122-129

Farag MA, Shehata NF, Mahmoud YA (2009) Predicting the annual generation peaks of peach fruit fly, Bactrocera zonata (Saunders) (Diptera: Tephritidae) using heat units accumulation at Giza governorate, Egypt. The $4^{\text {th }}$ Conference on Recent Technologies in Agriculture, Cairo University 2009, Egypt

Hamdy MK (1990a) A rapid method for timing the probable generations of the oleander scale, Aspidiotus hederae (Vallot) in the field. Zagazig J Agric Res 17(5b):1659-1667

Hamdy M (1990b) Prediction of the crawler abundance of the pallid scale, Lapidosapbes pallida (green) on mango trees in Sharkia governorate. Zagazig J Agric Res 17(5b):1715-1719

Jasic I (1975) On the life cycle of Perillus bioculatus (Heteroptera: Pentatomidae) in Slovakia, Acta ent. Bihemoslov 72:383-390

Moussa S, Baiomy F, Sharma A, Eid El-Adl F (2013) The status of tomato leaf miner; Tuta absoluta (Meyrick) (Lepidoptera: Gelechiidae) in Egypt and potential effective pesticides. Academic J Entomol 6(3):110-115

Salama, H. S.; Ismail, A. I.; Fouda, M; Ebada, I and Shehata, I. B (2014) Potency of the entomopathogenic nematodes on the tomato leaf miner Tuta absoluta (Meyrick) (Lepidoptera: Gelechiidae). Bull. NRC. Egypt, 39 (1): 43-54 (2014). Egypt.

Salama, H. S.; Ismail, A. I.; Fouda, M; Ebada, I and Shehata, I. B (2015) Thermal requirements and developmental zero of the tomato leaf miner Tuta 10. 1186/s42269-019-0123-9 absoluta (Meyrick), (Lepidoptera: Gelechiidae). Bull. NRC., Egypt, 40 (1): 1-16 (2015). Egypt.

Sannino L, Espinosa B (2010) Incidenza di Tuta absoluta sulla produzione di pomodoro. L'informatore Agrario 10:37-40
Sevacherian V, Steenwy NC, Van-Sharma KRK, Senders RR (1977) Forecasting pink bollworm emergence by thermal summation. Environ Entomol 6: 545-556

Varges H (1970) Observaciones sobre la biologia enemigos naturales de laspolilla del tomate, Gnorimoschema absoluta (Meyrick). Idesia 1:75-110

Vercher R, Calabuig A, Felipe C (2010) Ecología, muestreos y umbrales de Tuta absoluta (Meyrick). Phytoma España 217:23-26

Zalom F, Goodell P, Wilson L, Barnett W, Bentley W (1983) Degree-days: the calculation and use of heat unit in pest management. Division of Agricultural and Natural Resources, University of California, Davis, p 10

Zalom F, Wilson $L$ (1982) Degree days in relation to an integrated pest management program. Division of Agricultural Sciences, University of California, Davis, p 2

\section{Submit your manuscript to a SpringerOpen ${ }^{\circ}$ journal and benefit from:}

- Convenient online submission

- Rigorous peer review

- Open access: articles freely available online

- High visibility within the field

- Retaining the copyright to your article

Submit your next manuscript at $\boldsymbol{\nabla}$ springeropen.com 